\title{
A STUDY OF MODIFIED BASSINI'S REPAIR (ANATOMICAL REPAIR) AND LICHTENSTEIN'S MESH HERNIOPLASTY
}

\author{
Dileep C. N1, Yashwanth C. $N^{2}$
}

${ }^{1}$ Resident, Department of Surgery and Emergency Medicine, Shyamanur Shivashankarappa Institute of Medical Sciences, Davanagere, Karnataka.

${ }_{2}^{2}$ Assistant Professor, Department of Surgery and Emergency Medicine, Kerala Medical College, Mangode, Palakkad, Kerala.

\section{ABSTRACT}

\section{BACKGROUND}

Inguinal hernia is one of the oldest maladies known and suffered by humans. Though there are many surgical techniques which are in practice, yet there is no unison as to which is the best technique- the one with least or no recurrence rate. Our hospital being in a rural area, catering to majority of poor patients, anatomical and mesh repairs are done.

Aims and Objectives- This study is done to determine the post-operative complications of hernia during the hospital stay by two techniques.

\section{MATERIALS AND METHODS}

A prospective observational study of 100 patients admitted for inguinal hernia, who met both the inclusion and exclusion criteria were subjected to detailed examination. The post-operative complications were observed, analysed and compared with other similar studies.

\section{RESULTS}

Of the 35 patients who underwent anatomical repair (Modified Bassini's), there were 2 recurrences over a period of 2 years. There was no recurrence at all in 65 patients who underwent mesh repair (Lichtenstein's mesh hernioplasty) during the same period.

\section{CONCLUSION}

The early post-operative complications like pain, haematoma, seroma and infection rates following either surgery are comparable. However, mesh hernioplasty is superior to Modified Bassini's with regards to recurrence. The limitations of the study are relatively small number of patients studied and relatively short period of study and follow-up.

\section{KEYWORDS}

Inguinal Hernia, Groin, Herniotomy, Bassini's, Lichtenstein's, Pain, Haematoma, Seroma, Infection, Recurrence.

HOW TO CITE THIS ARTICLE: Dileep CN, Yashwanth CN. A study of modified Bassini's repair (anatomical repair) and Lichtenstein's mesh hernioplasty. J. Evolution Med. Dent. Sci. 2018;7(15):1877-1882, DOI: 10.14260/jemds/2018/423

\section{BACKGROUND}

The history of hernia in toto is as old as the history of surgery. Inguinal hernia, presenting as a bulge in the groin is an ancient malady, probably as old as man himself. Hernia is the "protrusion of a viscous or part of the viscous through an abnormal opening in the walls of its containing cavity." Inguinal hernias are the commonest of all the hernias and surgery is the definitive treatment for hernia.

Hernia seems to be the result of bipedal posture of humans, as a consequence of bearing of intra-abdominal pressure against the lower abdominal wall, below the level of arcuate line. This is compounded by the evolutionary defect in humans- absence of posterior rectus sheath, below the level of arcuate line.1,2

Hernias have been treated since the dawn of civilisation. The earliest records of hernia are found in Egypt, dating as far back as 1500 BC. Greeks used trusses to treat inguinal hernias. The accurate description of the inguinal region in the 18th century paved the way for the development of the revolutionary surgical technique by Bassini in 1887. Since

'Financial or Other Competing Interest': None.

Submission 24-02-2018, Peer Review 22-03-2018,

Acceptance 28-03-2018, Published 09-04-2018.

Corresponding Author:

Yashwanth C. N,

\#788/3, Saraswathi Nagar,

Davanagere-577004, Karnataka.

E-mail: dryashwanthcn@yahoo.co.in

DOI: $10.14260 /$ jemds $/ 2018 / 423$ then, many modifications of the Bassini's technique have been tried and practiced.

The study of the history of the surgical theory and technique of hernia repair points to the absence of a technique, which guarantees no recurrence. Numerous studies have been done to decide on the most suitable technique. But, there is no general agreement regarding the same.

Search for a near perfect modality of treatment of inguinal hernia has not yet ended. Recent introduction being Hernia System and Laparoscopic Repair of Inguinal Hernia. In spite of these, inguinal hernia still remains unconquered and poses a lot of challenge for all surgeons practicing hernia repairs.

Recurrence, after surgery for hernia has frustrated the surgeons for centuries. A search for a near perfect technique, which guarantees permanent cure (without recurrence) has been on for long. Controversy still exists as to which is the best technique of repair for treating inguinal hernias. ${ }^{3}$

In our institute two techniques of repair are usually undertaken-

- Modified Bassini's Repair (Anatomical Repair).

- Lichtenstein's Mesh Hernioplasty (Open Mesh Hernioplasty).

\section{Objective}

The present study has been done prospectively to determine the post-operative complications of hernia during the hospital stay by two techniques. 


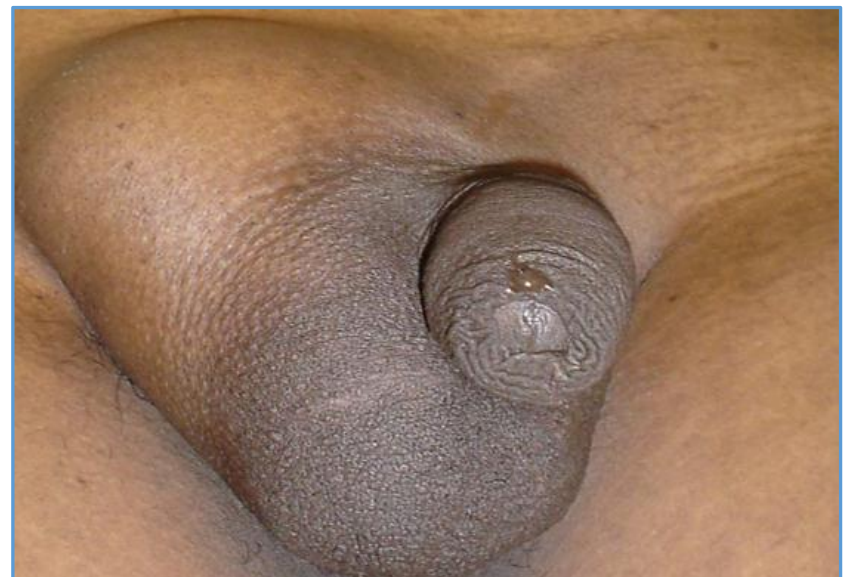

Left-Sided Indirect Inguinal Hernia

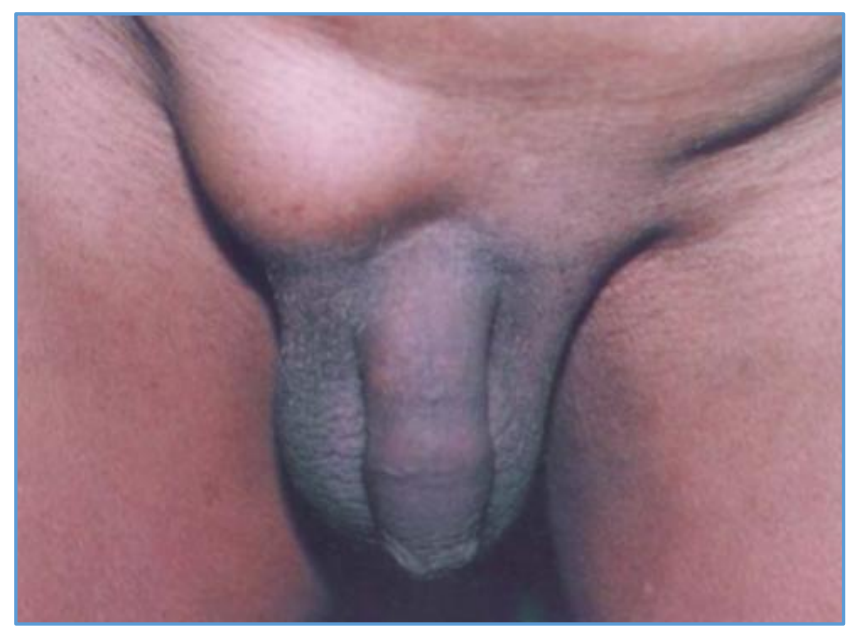

Right-Sided Direct Hernia

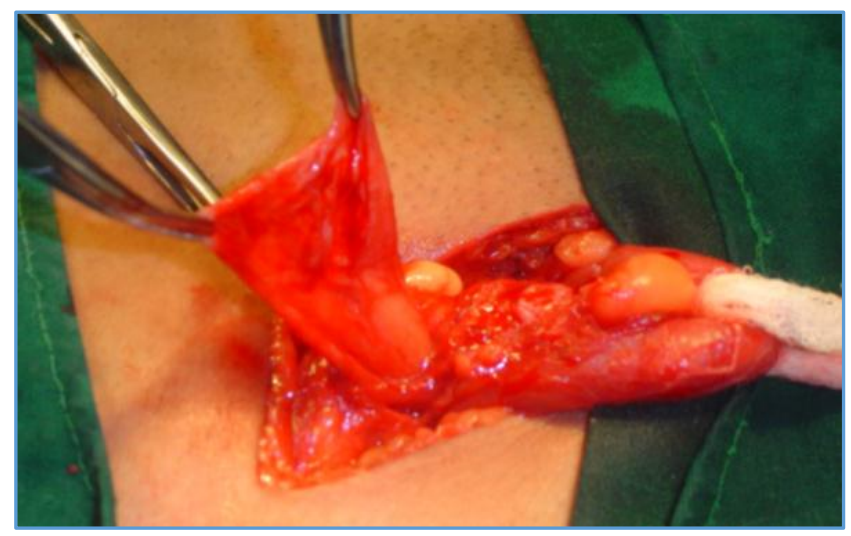

Indirect Hernia Sac Dissected

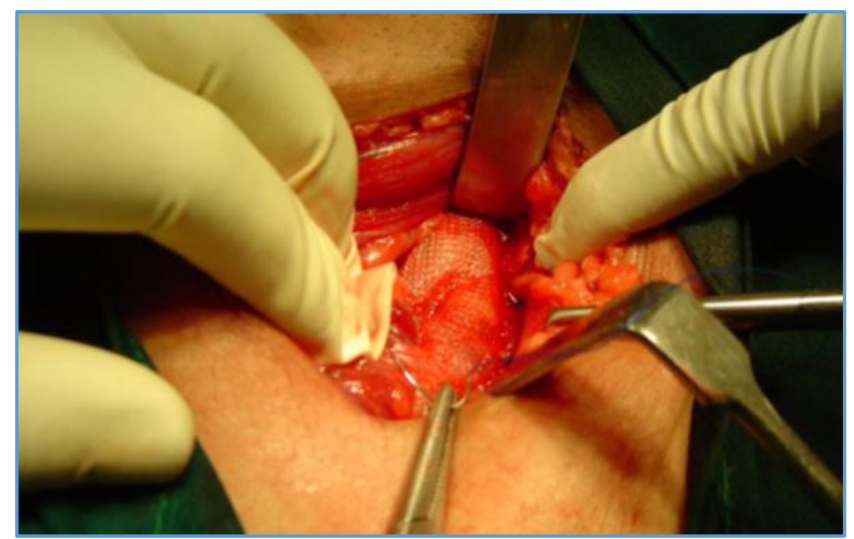

Mesh in Place- Lichtenstein's Repair

\section{MATERIALS AND METHODS}

\section{Source of Data}

Patients admitted in the surgical wards were included in the study without bias on a serial basis. This is a prospective observational study comprising 100 patients $(n=100)$ of Inguinal Hernia, which was taken for convenience.

\section{Method of Collection of Data \\ Inclusion Criteria}

All patients coming to the surgical outpatient department with complaints of inguinal hernia.

\section{Exclusion Criteria}

Patients presenting with congenital inguinal hernia, femoral hernia, other abdominal hernias, recurrent inguinal hernias and complicated inguinal hernias, patients below $18 \mathrm{yrs}$. and above 50 yrs.

\section{Investigations}

Diagnosis was based on clinical findings. Investigations were done to assess the fitness of patients for surgery-

1. Routine blood investigations- $\mathrm{Hb} \%$, BT, CT.

2. Routine urine examination for Albumin, Sugar and Microscopy.

3. Fasting blood sugar, post prandial blood sugar.

4. Blood urea, Serum creatinine.

5. Electrocardiogram.

6. Chest radiography.

7. Abdominopelvic Ultrasound. 4

If the patients were found to have any complicating medical conditions like Diabetes mellitus, Hypertension, Ischaemic heart disease and COPD, they were treated for the condition first and re-assessed for fitness for surgery. Patients were subjected to either Modified Bassini's Repair (Anatomical repair) or Lichtenstein's mesh hernioplasty (Mesh repair). All patients were given pre-operative prophylaxis with Inj. Cefotaxime 1 gm IV. Only spinal anaesthesia was administered to both the cohorts. For cohorts, classical incision was used, i.e. $2.5 \mathrm{cms}$ above and parallel to the medial three-fifths of the inguinal ligament. Only sharp dissection was preferred. In case of indirect hernia, herniotomy was performed. The posterior wall repair was done by either Modified Bassini's or Lichtenstein's mesh hernioplasty. The mesh was fixed. Postoperatively, Inj. Diclofenac $75 \mathrm{mg}$ IM BD was given as analgesia for 48 hours to both the cohorts. Post-operatively, Inj. Cefotaxime $1 \mathrm{gm} \mathrm{IV}$ BD was given for 48 hours to both the cohorts. 5,6

Postoperatively, Patients were evaluated for the Following Complications

- $\quad$ Pain- Treated by Inj. Tramadol IV where relevant.

- Haematoma- Evacuated when required.

- Seroma- Drained where relevant.

- Infection- Confirmed by culture and sensitivity and treated by drainage and appropriate antibiotics.

Patients were discharged when considered fit to go about their normal routine. Sutures were removed on 7 th day postoperatively. Patients were followed up once a month for the first three months, once every three months, thereafter in first year and once in six months in the next year and looked for recurrence. 


\section{Statistical Analysis}

The results were compared, and significance of the difference was inferred by applying and calculating according to "ChiSquare Test." Ethical clearance had been obtained from the institution for the present study.

\section{RESULTS}

The results of the study were as follows-

\begin{tabular}{|c|c|c|}
\hline $\begin{array}{c}\text { Age Group } \\
\text { (Years) }\end{array}$ & $\begin{array}{c}\text { Present Study (No. of } \\
\text { Cases) }\end{array}$ & Percentage \\
\hline$\leq 20$ & 4 & 4 \\
\hline $21-30$ & 30 & 30 \\
\hline $31-40$ & 14 & 14 \\
\hline $41-50$ & 52 & 52 \\
\hline \multicolumn{3}{|c|}{ Table 1. Age at Presentation } \\
\hline
\end{tabular}

The age of the patients ranged between 18 years and 50 years. In the present study, $4 \%$ of patients were less or equal to 20 years, $30 \%$ of patients were between 21 - 30 years, $14 \%$ between 31 - 40 years and 52\% between 41 - 50 years. In the study, maximum number of patients presented between 41 and 50 years of age.

\begin{tabular}{|c|c|c|}
\hline Sex & Present Study & Percentage \\
\hline Male & 100 & 100 \\
\hline Female & 00 & 00 \\
\hline \multicolumn{3}{|c|}{ Table 2. Sex } \\
\hline
\end{tabular}

Over the period of study, only male patients presented with inguinal hernias.

\begin{tabular}{|c|c|c|}
\hline $\begin{array}{c}\text { Mode of } \\
\text { Presentation }\end{array}$ & No. of Patients & Percentage \\
\hline Swelling only & 60 & 60 \\
\hline Swelling with pain & 40 & 40 \\
\hline \multicolumn{2}{|c|}{ Table 3. Mode of Presentation } \\
\hline
\end{tabular}

Without exception, all the patients presented with a swelling. Of these $60 \%$ of patients presented with swelling only, while $40 \%$ patients presented with both swelling and pain.

\begin{tabular}{|c|c|c|}
\hline Type & No. of Cases & Percentage \\
\hline Direct & 36 & 36 \\
\hline Indirect & 64 & 64 \\
\hline \multicolumn{3}{|c|}{ Table 4. Type of Hernia } \\
\hline
\end{tabular}

In the present study, 36\% cases were of direct type and $64 \%$ cases were of indirect type.

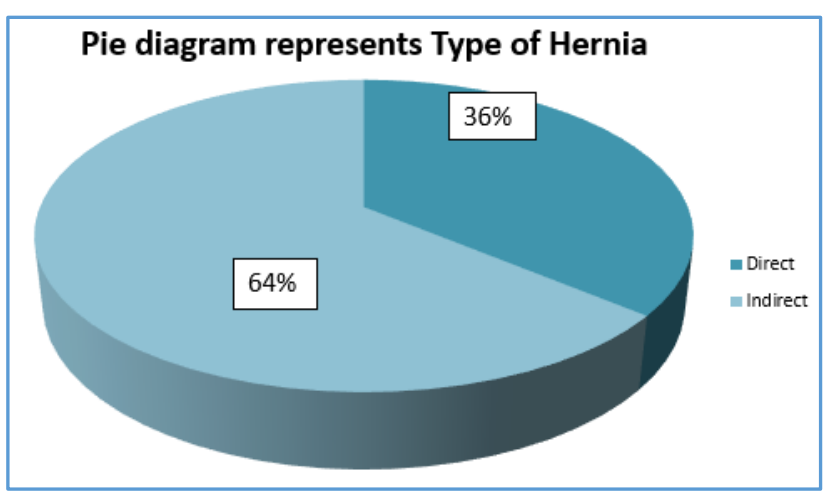

Graph I

\begin{tabular}{|c|c|c|}
\hline Location & No. of Patients & Percentage \\
\hline Right & 60 & 60 \\
\hline Left & 33 & 33 \\
\hline Bilateral & 7 & 7 \\
\hline \multicolumn{2}{|c|}{ Table 5. Location of Hernia } \\
\hline
\end{tabular}

In the present study $60 \%$ of cases had right-sided hernias, $33 \%$ had left-sided hernias and $7 \%$ had bilateral hernias.

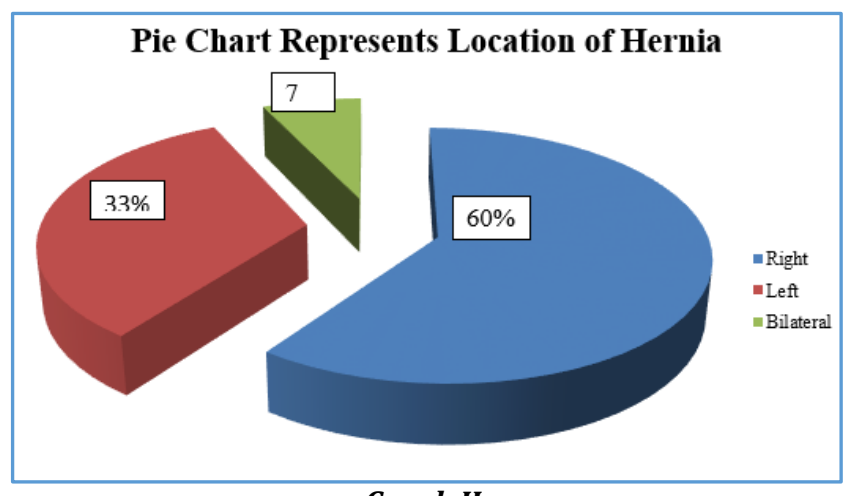

Graph II

\begin{tabular}{|c|c|c|}
\hline Predisposing Factors & No. of Patients & Percentage \\
\hline Bladder outlet obstruction & 8 & 8 \\
\hline Chronic cough & 18 & 18 \\
\hline Chronic constipation & 5 & 5 \\
\hline Smoking & 25 & 25 \\
\hline Obese & 6 & 6 \\
\hline No obvious factor & 38 & 38 \\
\hline \multicolumn{2}{|c|}{ Table 6. Predisposing Factors } \\
\hline
\end{tabular}

In the present study $8 \%$ of the patients had a history of bladder outlet obstruction, $18 \%$ had chronic cough (not due to smoking), $5 \%$ had a history of chronic constipation, $25 \%$ were smokers and $6 \%$ were obese. $38 \%$ of patients had no obvious predisposing factor.

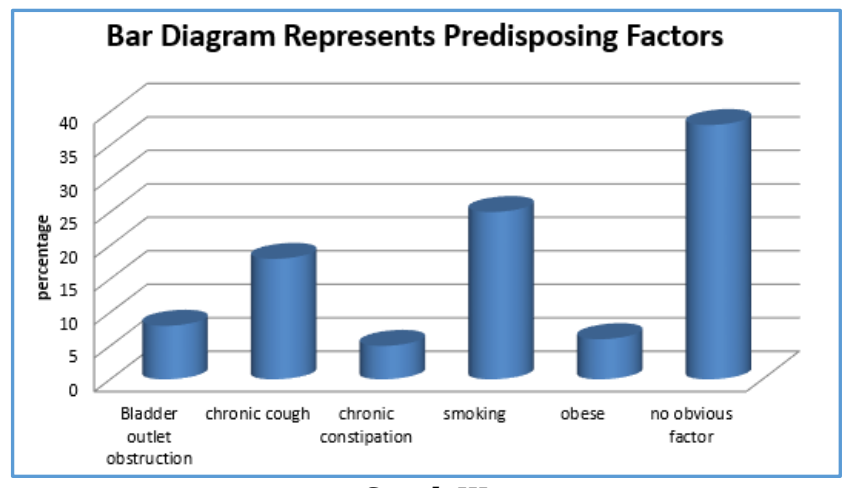

Graph III

\begin{tabular}{|c|c|c|}
\hline Duration & No. of Patients & Percentage \\
\hline Less than 6 months & 12 & 12 \\
\hline 6 months - 12 months & 50 & 50 \\
\hline More than 12 months & 38 & 38 \\
\hline \multicolumn{2}{|r|}{ Table 7. Duration of Illness } \\
\hline
\end{tabular}

Majority of the patients, i.e. $62 \%$ of patients presented and were operated within one year of the onset of the hernia. Only $38 \%$ patients presented later than a year for operation. 


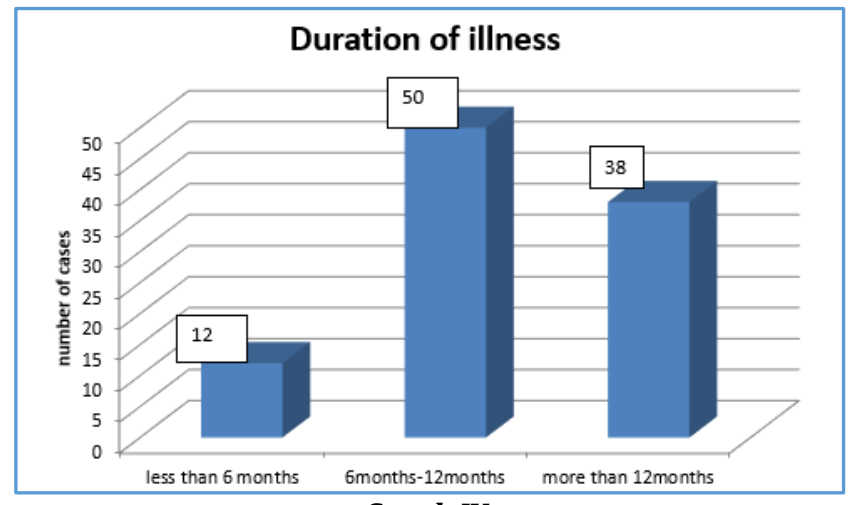

Graph IV

\begin{tabular}{|c|c|c|}
\hline Occupation & No. of Patients & Percentage \\
\hline Heavy work & 55 & 55 \\
\hline Moderate work & 45 & 45 \\
\hline \multicolumn{2}{|r|}{ Table 8. Relation with Occupation } \\
\hline
\end{tabular}

The present study shows that $55 \%$ of patients were involved in heavy and strenuous work like agricultural labour, manual labour and coolie. $45 \%$ of patients were involved with moderate work like students, teachers, drivers, cooks, businessmen and vegetable vendors.

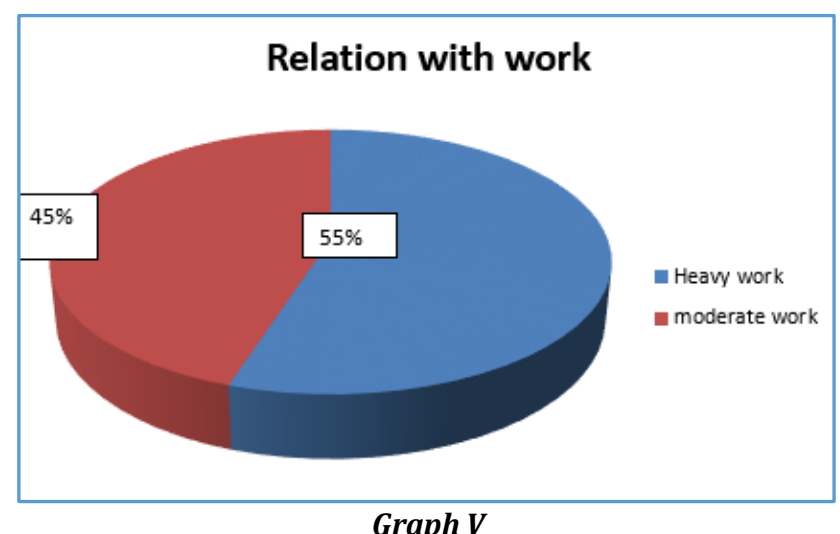

\begin{tabular}{|c|c|c|}
\hline Repair & No. of Patients & Percentage \\
\hline Modified Bassini's & 35 & 35 \\
\hline Lichtenstein's mesh & 65 & 65 \\
\hline \multicolumn{2}{|c|}{ Table 9. Technique of Repair } \\
\hline \multicolumn{2}{|c|}{}
\end{tabular}

In the above study, $35 \%$ of cases were treated with Bassini's repair and $67 \%$ with Lichtenstein's mesh hernioplasty. Only spinal anaesthesia was administered for surgery. In case of bilateral hernias, surgery was done on only one side.

\section{Immediate Post-Operative Complications: Comparison}

1. Pain.

\begin{tabular}{|c|c|c|c|}
\hline Type of Repair & $\begin{array}{c}\text { No. of } \\
\text { Patients c/o } \\
\text { Pain }\end{array}$ & $\begin{array}{c}\text { No. of Patients } \\
\text { in Each Group }\end{array}$ & Percentage \\
\hline Lichtenstein's & 20 & 65 & 30.76 \\
\hline $\begin{array}{c}\text { Modified } \\
\text { Bassini's }\end{array}$ & 12 & 35 & 34.28 \\
\hline \multicolumn{4}{|c|}{ Table 10. Pain } \\
\hline
\end{tabular}

$\mathrm{p}>0.05(0.7971$ chi-square test $)$
In the present study, $30.76 \%$ of patients who had undergone Lichtenstein's mesh hernioplasty complained of pain and $34.28 \%$ of patients who had undergone Modified Bassini's repair complained of pain.

\section{Modified Bassini's Repair c/o Pain}

By applying "Chi-square" test, p-value was found to be greater than 0.05 (insignificant). ${ }^{7}$

\section{Haematoma}

\begin{tabular}{|c|c|c|c|}
\hline $\begin{array}{c}\text { Type of } \\
\text { Repair }\end{array}$ & $\begin{array}{c}\text { No. of Patients } \\
\text { Developing } \\
\text { Haematoma }\end{array}$ & $\begin{array}{c}\text { No. of } \\
\text { Patients } \\
\text { in Each } \\
\text { Group }\end{array}$ & Percentage \\
\hline Lichtenstein's & 5 & 65 & 7.69 \\
\hline $\begin{array}{c}\text { Modified } \\
\text { Bassini's }\end{array}$ & 3 & 35 & 8.57 \\
\hline \multicolumn{4}{|c|}{ Table 11. Haematoma } \\
\hline
\end{tabular}

p > 0.05 (0.808 after Yates' correction)

In our study, $7.69 \%$ and $8.57 \%$ of patients undergoing Lichtenstein's mesh repair and modified Bassini's repair developed haematoma respectively. The difference was insignificant ( $p$-value $>0.05$ )

\section{Seroma}

\begin{tabular}{|c|c|c|c|}
\hline $\begin{array}{c}\text { Type of } \\
\text { Repair }\end{array}$ & $\begin{array}{c}\text { No. of Patients } \\
\text { Presenting with } \\
\text { Seroma }\end{array}$ & $\begin{array}{c}\text { No. of } \\
\text { Patients } \\
\text { in Each } \\
\text { Group }\end{array}$ & Percentage \\
\hline Lichtenstein's & 12 & 65 & 18.46 \\
\hline $\begin{array}{c}\text { Modified } \\
\text { Bassini's }\end{array}$ & 6 & 35 & 17.14 \\
\hline \multicolumn{3}{|c|}{ Table 12. Seroma } \\
\hline
\end{tabular}

$\mathrm{p}>0.05(0.891$ chi-square test $)$

In the present study, $18.46 \%$ of patients who had undergone Lichtenstein's mesh hernioplasty developed seroma and $17.14 \%$ of patients who had undergone modified Bassini's repair developed seroma.

Here, the p-value was found to be insignificant, i.e. greater than 0.05 .

4. Infection

\begin{tabular}{|c|c|c|c|}
\hline $\begin{array}{c}\text { Type of } \\
\text { Repair }\end{array}$ & $\begin{array}{c}\text { No. of Patients } \\
\text { with Infection }\end{array}$ & $\begin{array}{c}\text { No. of Patients } \\
\text { in Each Group }\end{array}$ & Percentage \\
\hline Lichtenstein's & 5 & 65 & 7.67 \\
\hline $\begin{array}{c}\text { Modified } \\
\text { Bassini's }\end{array}$ & 3 & 35 & 8.57 \\
\hline \multicolumn{4}{|c|}{ Table 13. Infection } \\
\hline
\end{tabular}

$\mathrm{p}>0.05$ (0.086 after Yates' correction)

In the present study, $7.67 \%$ of cases who had undergone Lichtenstein's mesh hernioplasty and $8.57 \%$ of patients who had undergone modified Bassini's repair developed postoperative wound infection. P-value was insignificant $(\mathrm{p}>$ 0.05). In a study by Bholla Singh Sidhu et al, wound infection rate was $6 \% .8,9$ 


\section{Recurrence}

\begin{tabular}{|c|c|c|c|}
\hline $\begin{array}{c}\text { Type of } \\
\text { Repair }\end{array}$ & $\begin{array}{c}\text { No. of } \\
\text { Patients } \\
\text { with } \\
\text { Recurrence }\end{array}$ & $\begin{array}{c}\text { No. of } \\
\text { Patients in } \\
\text { Each Group }\end{array}$ & Percentage \\
\hline Lichtenstein's & None & 65 & - \\
\hline $\begin{array}{c}\text { Modified } \\
\text { Bassini's }\end{array}$ & 2 & 35 & 5.71 \\
\hline \multicolumn{3}{|c|}{ Table 14. Recurrence } \\
\hline
\end{tabular}

p > 0.05 (0.2499 after Yates' correction)

In the present study, there were $2(5.71 \%)$ recurrences in patients who had undergone Modified Bassini's herniorrhaphy and none, following Lichtenstein's mesh hernioplasty. ${ }^{10,11,12,13}$ The $\mathrm{p}$-value was found to be greater than 0.05 .

\section{Duration of Hospital Stay}

\begin{tabular}{|c|c|c|}
\hline Stay in Days & Modified Bassini's & Lichtenstein's \\
\hline Ave. hospital stay & 5.6 days & 4.8 days \\
\hline$\leq 7$ days & $29(82.85 \%)$ & $55(84.61 \%)$ \\
\hline$>7$ days & $6(17.14 \%)$ & $10(15.38 \%)$ \\
\hline \multicolumn{3}{|c|}{ Table 15. Average Number of Days of Hospital Stay } \\
\hline
\end{tabular}

In the present study, patients who had undergone Modified Bassini's repair had on an average stayed for 5.6 days in the hospital as compared to 4.8 days following Lichtenstein's mesh repair. Following Bassini's repair, 6 cases stayed beyond 7 days accounting for $17.14 \%$ of cases, while following Lichtenstein's mesh repair 10 cases $(23.08 \%)$ stayed for more than 7 days.

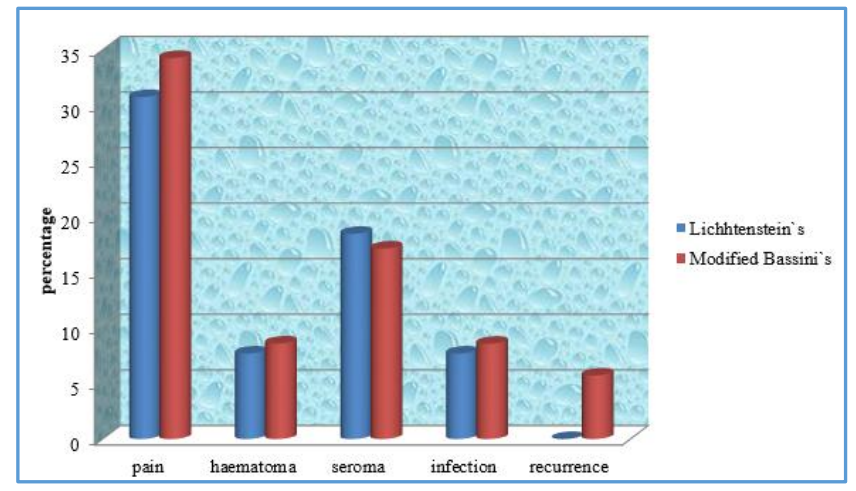

Graph VI. Bar Diagram Comparing Postoperative Complications of Lichtenstein's and Modified Bassini's Repairs

\section{DISCUSSION}

The study shows that they are at the disposal of a surgeon, a plethora of techniques for the repair of inguinal hernias. In the light of this, it becomes relevant to study the advantages and disadvantages of various techniques and decide which technique is statistically superior and suitable to patients coming to our institute. Traditionally, modified Bassini's repair was the most popular repair technique.

Advances in the understanding of the pathophysiology of recurrence have led to the conclusion that in this technique tissues are approximated under tension. This is a cardinal, if not the most important factor in the failure of the hernia repair. Tissues approximated under tension tend to pull apart, but are prevented by the sutures. An area of ischaemic necrosis develops near the point of contact between sutures and tissues. This process of ischaemic necrosis proceeds until tissues have returned to their original position and hernia recurs through the consequent gap. This is more so in case of recurrent hernia, where tissues have been distorted by previous surgery. Lichtenstein, Bendavid, Gilbert and Rutkow mesh repairs are all based on absolute tensionlessness.

The other short-term complications following modified Bassini's repair and prolene mesh hernioplasty need to be studied, as higher incidence of complications may outweigh the lower recurrence rates. Results published worldwide vouch for the superior results of mesh repair over that of conventional tissue repair like the one given by Bendavid after a review of literature.

\section{CONCLUSION}

In the present study, 35 patients with inguinal hernia who had undergone modified Bassini's repair were compared with 65 patients with inguinal hernia who had undergone Lichtenstein's mesh hernioplasty. After analysing the data and observations, the following are the conclusions from the present study-

- $\quad$ The age of the patients ranged between 18 years and 55 years. Maximum number of patients presented between 41 and 50 years of age.

- Male are predominantly affected with inguinal hernias.

- Swelling only was the predominant presentation in most of the patients, whereas $40 \%$ patients presented with both swelling and pain.

- Incidence of Indirect hernias was almost twice than that of direct hernias.

- $\quad$ Right-sided hernias are the commonest followed by left-sided hernias. Bilateral hernias were few in number.

- More than half of the patients had some predisposing factors like bladder outlet obstruction, chronic cough, chronic constipation or strenuous work. Rest had no obvious predisposing factor.

- Most of the patients presented and were operated within one year of the onset of the hernia.

- Post-operative pain was almost the same following either surgery, but patient undergoing mesh repair had pain of less intensity.

- Post-operative haematoma occurrence was almost of same magnitude following either surgery.

- Occurrence of seroma following mesh repair was slightly more than following Bassini's repair.

- Post-operative wound infection was slightly more following mesh repair than following Bassini's repair.

- The average duration of hospital stay in patients who had undergone modified Bassini's repair was slightly longer than following Lichtenstein's mesh hernioplasty.

- There were no recurrences in patients who had undergone Lichtenstein's mesh hernioplasty and 2 (5.71\%) recurrences in patients who had undergone modified Bassini's repair over the period of study. Though the present comparative study does not show any distinct advantages of one repair over the other, Lichtenstein's mesh hernioplasty gives superior results compared to modified Bassini's repair with regards to 
recurrence. However, the sample size and the follow up period in the current study being relatively short, a larger study sample and a longer follow-up study may be needed before any further conclusions can be made.

\section{REFERENCES}

[1] McMinn RMH. Lasts anatomy. Regional and applied. 9th edn. New York: Churchill Livingstone 1996.

[2] Condon RE. Historical survey of the treatment of Hernia. Chapter - 1. In: Lloyd NM, Condon RE. eds. Hernia. Philadelphia: JB Lippincott Company 1995: p. 3-13.

[3] Eubanks S. Hernias. Chapter - 37. Textbook of surgery - the biological basis of modern surgical practice. In: Sabiston DC. edr. Philadelphia: WB Saunders 2001: p. 1215-26.

[4] John SE, Gray SW, Ekin JT. The surgical anatomy of hernial rings. Surgical Clinics of North America. Philadelphia: WB Saunders Co 1974;54:1227-46.

[5] Rutkow IM. A selective history of groin hernia surgery in the early 19th century. Surgical Clinics of North America 1998;78(6):921-40.

[6] Mokete M, Earnshaw J. Evolution of an inguinal hernia surgery practices. Postgrad Medical Journal 2001;77(905):189-90.
[7] Lichtenstein IL. Hernia repair without disability: a surgical atlas illustrating the anatomy, technique and physiologic rationale of the One Day Hernia. Saint Louis: The C.V. Mosby Company, 1970: p. 1274-9.

[8] Pullyblank AM, Carney L, Braddon F, et al. Laparoscopic inguinal hernia repair - a nice operation. J R Coll Surg Edinb 1999;47(4):630-3.

[9] John S. Embryologic and anatomic basis of inguinal herniorrhaphy. Surgical Clinics of North America. Philadelphia: W B Saunders Co 1993;73:799-834.

[10] Read RC. Historical survey of the treatment of hernia. Chapter - 1. In: Lloyd NM, Condon RE, eds. Hernia. Philadelphia: J.B. Lippincott Company 1995: p. 556-79.

[11] Lloyd NM, Condon RE. The pre-peritoneal approach and iliopubic tract repair of inguinal hernia. Hernia. Philadelphia: J.B. Lippincott Company 1995: p. 585600 .

[12] Gilbert AI, Graham MF, Voigt WJ. A bilayer patch device for inguinal hernia repair. Hernia 1999;3(3):161-6.

[13] Palanivelu C. Results of hand sutured laparoscopic hernioplasty - effective method of repair. Indian Journal of Surgery 2000;62(5):339-41. 